\title{
Article \\ Application of Lactiplantibacillus plantarum SCH1 for the Bioconservation of Cooked Sausage Made from Mechanically Separated Poultry Meat
}

\author{
Beata Łaszkiewicz $^{1, *(\mathbb{D})}$, Piotr Szymański ${ }^{1}\left(\mathbb{D}\right.$, Dorota Zielińska $^{2} \mathbb{D}$ and Danuta Kołożyn-Krajewska ${ }^{2}(\mathbb{D}$ \\ 1 Department of Meat and Fat Technology, Prof. Waclaw Dabrowski Institute of Agricultural and Food \\ Biotechnology—State Research Institute, 36 Rakowiecka St, 02-532 Warsaw, Poland; piotr.szymanski@ibprs.pl \\ 2 Institute of Human Nutrition Sciences, Warsaw University of Life Sciences-SGGW, 166 Nowoursynowska St, \\ 02-787 Warsaw, Poland; dorota_zielinska@sggw.edu.pl (D.Z.); \\ danuta_kolozyn_krajewska@sggw.edu.pl (D.K.-K.) \\ * Correspondence: beata.laszkiewicz@ibprs.pl; Tel.: +48-22-509-70-25
}

check for updates

Citation: Łaszkiewicz, B.; Szymański, P.; Zielińska, D.; Kołożyn-Krajewska, D. Application of Lactiplantibacillus plantarum $\mathrm{SCH} 1$ for the Bioconservation of Cooked Sausage Made from Mechanically Separated Poultry Meat. Appl. Sci. 2021, 11, 1576. https://doi.org/ 10.3390/app11041576

\section{Academic Editor:}

Małgorzata Karwowska

Received: 14 January 2021

Accepted: 3 February 2021

Published: 9 February 2021

Publisher's Note: MDPI stays neutral with regard to jurisdictional claims in published maps and institutional affiliations.

Copyright: (c) 2021 by the authors. Licensee MDPI, Basel, Switzerland. This article is an open access article distributed under the terms and conditions of the Creative Commons Attribution (CC BY) license (https:/ / creativecommons.org/licenses/by/ $4.0 /)$.

\begin{abstract}
The aim of the research was an assessment of the effect of the Lactiplantibacillus plantarum $\mathrm{SCH} 1$ strain isolated from ecological raw fermented pork roast on $\mathrm{pH}$, redox potential, nitrites, and nitrates content, $\mathrm{L} \mathrm{a}^{*} \mathrm{~b}^{*}$ color parameters, total heme pigments content, nitrosyl myoglobin concentration, as well as the microbiological quality and sensory traits of cooked sausages produced from mechanically separated poultry meat (MSPM), cured with a lower sodium nitrite level $\left(\mathrm{NaNO}_{2}\right.$ $50 \mathrm{mg} / \mathrm{kg}$ ) after production as well as after storage (1 and 3 weeks of storage). The biochemical identification of the Lactobacillus bacteria after storage was also performed. Tests were performed in two sausage treatments: C—control sausage made from MSPM and L-sausage made from MSPM inoculated with L. plantarum at approx. $10^{7} \mathrm{cfu} / \mathrm{g}$. No negative effect of using the L. plantarum SCH1 strain on the physical and chemical MSPM sausage features was found. The treatment with $L$. plantarum SCH1 was of better microbiological quality after 3 weeks of storage. The sausages with $L$. plantarum SCH1 kept good sensory quality while the control treatment was spoiled after storage.
\end{abstract}

Keywords: Lactiplantibacillus plantarum; sausage with MSPM; biopreservation; quality

\section{Introduction}

Mechanically separated meat (MSM) is widely used in the meat industry and is one of the cheapest animal origin materials [1]. In recent years, Poland has become one of the biggest poultry meat producers in Europe [2]. Mechanically separated poultry meat (MSPM) production can fully exploit soft tissue residues from the bones and poultry carcasses remaining after hand deboning [1].

The most commonly used separators in MSM production are high-pressure ones, low-pressure ones are used less commonly [3]. The risk of higher microorganism levels in the product increases together with the increased grinding level and increased muscle fiber degradation. Thus, MSPM obtained with the high-pressure method is a good substrate for microflora growth [3]. Excessive fragmentation of MSPM, decay of tissue structure and aeration during the separation process fosters microbiological pollution. What is more, the raw material for MSPM production might contain a relatively high number of microorganisms. In the MSM microflora, the following pathogenic may be present in the bacteria: Salmonella spp., Campylobacter spp., Escherichia coli, Listeria monocytogenes, Yersinia enterocolitica, Staphylococcus aureus, as well as saprophytic Pseudomonas, that speed up meat spoilage [4-8]. A substantial factor determining MSPM microbiological quality is the hygiene of carcass processing as well as the level and type of waste at the early production stage and during animal rearing [9]. MSPM is usually affected with microorganisms originating from chicken carcasses and bones as well as from the environment in which it is 
processed (service, equipment, and environment). Additionally, if the temperature during the deboning process is not low enough, the risk of bacteria multiplying increases [10]. The presence of many bacteria genus, including the pathogenic ones like Enterobacteriaceae and Salmonella in the raw material of poultry is well documented [7,11-13].

Due to low microbiological MSPM stability it should be sent for processing immediately after production or should be chilled to a temperature of $2{ }^{\circ} \mathrm{C}$. MSPM after chilling may be stored but not longer than $24 \mathrm{~h}$, which significantly hinders the logistics of processing the MSPM in the plant.

One of the methods which enables the lengthening of MSPM shelf-life is to apply the freezing process to $-18{ }^{\circ} \mathrm{C}$ [14]. Nevertheless, this process causes many negative changes within MSPM i.e., a worse water holding capacity, drip loss, color change, lower protein solubility and other changes [15]. In the industry the practice of curing fresh or defrosted MSPM with sodium nitrite is also applied. Considering the proven negative effect of nitrites and especially their derivates N-nitrosamines (NAs) on human health it is recommended to reduce their level in the diet [16]. Research has indicated that NAs formation depends on the level of nitrites added to meat $[17,18]$. In some countries e.g., in Denmark internal regulations were introduced to lower the maximum level of nitrites from $150 \mathrm{mg} / \mathrm{kg}$ allowed in the European Union to $60 \mathrm{mg} / \mathrm{kg}$ [19]. Reducing the amount of nitrites in cured MSPM batters may have an influence on their microbiological quality and thus have a negative effect on shelf-life and the hygienic security of products with MSPM content. Thus, it is important to look for new technological solutions that will constitute an additional barrier in the 'hurdle technology' in producing meat products with MSPM and lower sodium nitrite levels.

Lactic acid bacteria (LAB) plays an important role in the production of fermented meat products, they affect the taste and texture as well as extend the shelf-life of these products. They also may assure meat safety without any negative effects on product quality [20-22]. Lactic acid bacteria-i.e., Lactobacillus sakei, Pediococcus acidilactici, Lactobacillus curvatus - are used in order to increase raw meat products shelf-life and health safety [22]. The antimicrobial LAB activity is attributed to the metabolites produced by the bacteria cell. Apart from organic acids, hydrogen peroxide, diacetyl, and $\mathrm{CO}_{2}$, they also produce an abundant group of protein substances of significant antimicrobial and/or bacteriostatic activity called bacteriocins [23]. In the research of Łaszkiewicz et al. [24,25], it was proved that the Lactiplantibacillus plantarum SCH1 strain isolated from ecological raw fermented pork roast it is possible for it to be used to inhibit E. coli growth in raw uncured MSPM batter after 4 days of cold storage and also in raw MSPM batters cured with a lower amount of sodium nitrite $(50 \mathrm{mg} / \mathrm{kg})$ during storage. The results reported by other the authors indicate that some LAB strains are thermotolerant and thus could be used to elongate the shelf-life of cooked meat products [26,27]. In this research, the L. plantarum SCH1 strain was used in MSPM batter cured with a lower amount of sodium nitrite and next the model cooked meat product was formed for assessment.

The aim of the research was to assess the possibility of using Lactiplantibacillus plantarum SCH1 for the bioconservation of cooked sausage made from mechanically separated poultry meat cured with a reduced amount of sodium nitrite.

\section{Materials and Methods}

\subsection{Bacteria Culture and Growth Condition}

The Lactiplantibacillus plantarum SCH1 strain isolated from ecological raw fermented pork roast was used within the research. The strain originated from a microorganisms collection owned by the Facility of Food Hygiene and Quality Management, Warsaw University of Life Sciences in Poland and was chosen based on the research of Rzepkowska et al. [28] and Łaszkiewicz et al. [24,25]. Lactic bacteria cultures stored in $20 \%$ glycerol at $-80{ }^{\circ} \mathrm{C}$ were defrosted to prepare the strain for the research. The $20 \mu \mathrm{L}$ of the strain after mixing was put into $5 \mathrm{~mL}$ of MRS broth (Merck KGaA, Darmstadt, Germany) in sterile test tubes and incubated at $37^{\circ} \mathrm{C}$ for $24 \mathrm{~h}$. After the next decimal dilution and incubation in 
the same conditions the cells were centrifuged in a J2-21 centrifuge (Beckman, Birkerød, Denmark) at $4500 \mathrm{RPM}(2313 \times g)$. Then, after removing supernatant bacteria cells, it was suspended in a $\mathrm{NaCl}$ solution $(0.9 \%)$ and applied into the MSPM batter to reach the bacteria concentration of approx. $10^{7} \mathrm{cfu} / \mathrm{g}$. All of the procedures were performed aseptically using sterile equipment.

\subsection{Preparing Batters and Producing Sausages with MSPM}

High pressure MSPM was obtained in industrial conditions (diameter of the holes was $1 \mathrm{~mm}$ ). Non-frozen chicken carcasses were deboned using the separator (AM2C, Quimper, France) and after separation the obtained MSPM was divided into blocks of $10 \mathrm{~kg}$ each and frozen to $-18{ }^{\circ} \mathrm{C}$. The blocks of MSPM were stored frozen for $2-4$ days. For producing the sausage batters, the blocks of MSPM were defrosted in refrigerated conditions $\left(4-6{ }^{\circ} \mathrm{C}\right)$ for approx. $24 \mathrm{~h}$. Two MSPM batter treatments were prepared for sausage production: C-control treatment produced with MSPM cured with $50 \mathrm{mg} / \mathrm{kg}$ of sodium nitrite, L-treatment produced with MSPM cured with $50 \mathrm{mg} / \mathrm{kg}$ of sodium nitrite with the addition of Lactiplantibacillus plantarum SCH1 at about $10^{7} \mathrm{cfu} / \mathrm{g}$.

In the $\mathrm{L}$ treatment, the bacterial biomass suspended in the physiological saline $(1.25 \mathrm{~kg})$ was added to $10 \mathrm{~kg}$ of defrosted MSPM. In the C treatment, physiological saline $(1.25 \mathrm{~kg})$ without bacteria was added to the $10 \mathrm{~kg}$ of MSPM. Next, the MSPM (C and L) were mixed separately in the mixer (N-50G, Hobart Corporation, Troy, OH, USA) for $1 \mathrm{~min}$ and left in polypropylene containers ( $48 \mathrm{~L}$ capacity) for 4 days in cold storage at a temperature of $4{ }^{\circ} \mathrm{C}$. Time and storing conditions were established based on the preliminary research [24,25]. Next, water/ice, sodium nitrite $(50 \mathrm{mg} / \mathrm{kg}$ ), spices, and additional substances (Table 1) were added to the MSPM (C and L) and after that it was minced in a cutter K40 (Seydelmann, Stuttgart, Germany), reaching up to $10^{\circ} \mathrm{C}$ in the batter. The MSPM batters were stuffed into the semi-permeable casings (DAT SCHAUB, Suchy Las, Poland). After stuffing, the sausages were allowed to settle for $45 \mathrm{~min}$ at a temperature of $20-25^{\circ} \mathrm{C}$.

Table 1. Model sausage with the MSPM formula.

\begin{tabular}{ccc}
\hline Formula Ingredient [kg]/Experimental Treatment & C & L \\
\hline MSPM & 100.00 & 100.00 \\
Bacterial biomass Lactiplantibacillus plantarum SCH1 suspended in $\mathrm{NaCl}$ & - & 1.25 * \\
0.9\% solution & $1.25 *$ & - \\
NaCl 0.9\% solution & 30.00 & 30.00 \\
Water/ice & 0.0070 & 0.0070 \\
Sodium nitrite & 0.33 & 0.33 \\
Sodium triphosphate (Tari P-31: 57\% $\left.\mathrm{P}_{2} \mathrm{O}_{5}\right)$ & 0.05 & 0.05 \\
Sodium ascorbate & 2.30 & 2.30 \\
Sodium chloride & 2.00 & 2.00 \\
SUPR 595 protein & 2.50 & 2.50 \\
Potato starch & 0.40 & 0.40 \\
Carrageenan & 0.25 & 0.25 \\
Black pepper & 0.07 & 0.07 \\
Marjoram & 0.05 & 0.05 \\
Fresh garlic & 137.96 & 137.96 \\
Total & & \\
\hline
\end{tabular}

* Added before cold storage; C-control treatment with MSPM without a bacteria strain, L-treatment with MSPM and the bacteria L. plantarum SCH1 $\left(10^{7} \mathrm{cfu} / \mathrm{g}\right)$.

After that the sausages were smoked with hot smoke $56-65^{\circ} \mathrm{C}$ for $50 \mathrm{~min}$ and then steamed to $70-72{ }^{\circ} \mathrm{C}$ up to reaching a final internal sausage temperature of $70^{\circ} \mathrm{C}$. The final products were chilled with water to $15-20^{\circ} \mathrm{C}$, and next additionally chilled with cold air in the cold store to $4-6{ }^{\circ} \mathrm{C}$.

The tests of the model sausages with MSPM were performed after thermal treatment and chilling (after production) as well as at 1 and 3 weeks of storage. The experimental production was done in the technical hall of the Department of Meat and Fat Technology, 
Institute of Agricultural and Food Biotechnology in Warsaw (Poland). The experiment described above was repeated three times $(n=3)$ in independent trials (replicates).

\section{3. $\mathrm{pH}$ Measurement}

The $10 \mathrm{~g}$ meat product samples were mixed with $50 \mathrm{~mL}$ distilled water and homogenized (14.000 RPM) for 1 min with an 800 W blender (MSM 66120, BSH Hausgeräte GmbH, Munich, Germany). To determine the $\mathrm{pH}$ value a digital $\mathrm{pH}$-meter (Mettler Delta 350, Mettler Toledo, Schwerzenbach, Switzerland) with an automatic compensation of temperature and a glass-calomel In a Lab Cool electrode (Mettler Toledo, Greifensee, Switzerland) was used.

\subsection{Oxidative-Reduction Potential (ORP) Measurement}

To determine the ORP value the $10 \mathrm{~g}$ meat product samples were mixed with $50 \mathrm{~mL}$ distilled water and homogenized (14.000 RPM) for 1 min with an $800 \mathrm{~W}$ blender (MSM 66120, BSH Hausgeräte $\mathrm{GmbH}$, Munich, Germany). The redox potential was performed using a digital pH-meter (Mettler Delta 350, Mettler Toledo, Schwerzenbach, Switzerland) equipped with an In Lab Redox Pro electrode (Mettler Toledo, Greifensee, Switzerland). The obtained results were calculated into the value of ORP in relation to the standard hydrogen electrode $\mathrm{E}_{\mathrm{H}}(\mathrm{mv})$. The ORP value of the reference electrode at a temperature of $20^{\circ} \mathrm{C}-\mathrm{E}_{\text {ref }}=207 \mathrm{mV}$ was summed up with the value obtained with the equipment.

\subsection{Determining the Total Heme Pigments Content and Nitrosylmyoglobin Concentration}

The total heme pigments content and nitrosylmyoglobin concentration was performed using the Hornsey method [29]. To determine the absorbance of the filtrates value, a U-2900 spectrophotometer (Hitachi, Tokyo, Japan) was used. The total heme pigment content was measured in hematin ppm and was calculated by multiplying the absorbance at $640 \mathrm{~nm}$ by 680 . The nitrosylmyoglobin concentration (NO-Mb) content was calculated by multiplying the absorbance at $540 \mathrm{~nm}$ by 290 and was finally expressed in $\mathrm{g} / 100 \mathrm{~g}$ according to the formula

$$
\mathrm{NOMb}(\mathrm{g} / 100 \mathrm{~g})=\frac{\mathrm{NO}-\mathrm{Mb} \text { amount }(\mathrm{ppm})}{\text { total heme pigment amount }(\mathrm{ppm})} \times 100
$$

\subsection{Sodium Nitrite and Nitrate Content}

The content of nitrites and nitrates was performed according to PN-EN 120414:2006 with an amendment of Siu and Henshall [30]. The $10 \mathrm{~g}$ homogenized sausage sample was mixed with deionized water added to the volume of $50 \mathrm{~mL}$ into a volumetric flask and heated for $20 \mathrm{~min}$. at a temperature between $70-80^{\circ} \mathrm{C}$. After cooling, deionized water was added to the sample to a volume of $100 \mathrm{~mL}$ and mixed. The supernatant was filtered using cellulose acetate (CA) syringe filters (Alfatec Technology, Zagreb, Croatia) with a pore size of $0.45 \mu \mathrm{m}$ and after that the filtrate was used for the HPLC analysis.

For the extracts analysis an Agilent 1200 liquid chromatograph (Agilent Technologies, Waldbronn, Germany) with a UV detector, analytical column IonPac ${ }^{\circledR}$ AS11-HC $4 \times 250 \mathrm{~mm}$ (Thermo Fisher Scientific, Sunnyvale, CA, USA) and pre-column AG11-HC $4 \times 50 \mathrm{~mm}$ (Thermo Fisher Scientific, Sunnyvale, CA, USA) was used. Nitrate and nitrite were separated in isocratic conditions: $10 \mathrm{mmol} / \mathrm{L}$ sodium hydroxide (Chempur, Piekary Ślaskie, Poland) for $20 \mathrm{~min}$, then the column was washed with $50 \mathrm{mmol} / \mathrm{L}$ sodium hydroxide for $10 \mathrm{~min}$, and equilibrated with $10 \mathrm{mmol} / \mathrm{L}$ sodium hydroxide for $5 \mathrm{~min}$. The volume of the injection was $25 \mu \mathrm{L}$, the eluent flow-rate $1.5 \mathrm{~mL} / \mathrm{min}$ and analytes were detected at $225 \mathrm{~nm}$ with UV detection.

The content of nitrite and nitrate anions was expressed in terms of the salts: $\mathrm{NaNO}_{2}$ and $\mathrm{NaNO}_{3}$ in $\mathrm{mg} / \mathrm{kg}$. 


\subsection{Determination of Color}

To determine the color a spherical CR-300 spectrophotometer (Konica Minolta, Tokyo, Japan) with a measuring hole of $25.4 \mathrm{~mm}$ in diameter was used. The measurement was performed in a laboratory at a temperature of $24^{\circ} \mathrm{C} \pm 2{ }^{\circ} \mathrm{C}$. Computed trio-chromatic coordinates were expressed in the CIE $\mathrm{L}^{*} \mathrm{a}^{*} \mathrm{~b}^{*}$ system, where $\mathrm{L}^{*}$ means lightness, $\mathrm{a}^{*}$ chromaticity from green to red color and $\mathrm{b}^{*}$ chromaticity from blue to yellow color. For the measurement of the color, the standard CIE observer was used: $2^{\circ}$, illuminant D65, $8 \mathrm{~mm}$ measuring area and the white a tile standard $\left(\mathrm{L}^{*}=95.87, \mathrm{a}^{*}=-0.49, \mathrm{~b}^{*}=2.39\right)$ as a reference source was used. For each of the three replicate treatments $(C, L)$ four measurements were carried out. The $\mathrm{a}^{*} / \mathrm{b}^{*}$ ratio was also calculated [31].

\subsection{Microbiological Tests}

The scope of the MSPM sausages microbiological test in the first research stage (after production) was as follows: total viable counts (TVC), lactic acid bacteria counts, Escherichia coli counts, Enterobacteriaceae counts, coagulase positive Staphylococcus count and Salmonella spp., and Campylobacter spp. presence in $25 \mathrm{~g}$. The range and methodology of the microbiological tests are described below.

Samples of $10 \mathrm{~g}$ or $25 \mathrm{~g}$ were taken aseptically for quantity or quality lab measurements and after mixing the samples was suspended in $100 \mathrm{~mL}$ or in $250 \mathrm{~mL}$ of peptone water, respectively. Then, the decimal dilutions were used and bacteria growth on different culture media was performed.

To determine the presence of Salmonella spp. in $25 \mathrm{~g}$ the Müller-Kauffman's medium with tetrathionate and novobiocin (Oxoid Ltd., Basingstoke, Hampshire, UK), medium according to Rappaport-Vassilliads with soya (RVS, Oxoid Ltd., Basingstoke, Hampshire, UK), xylose lysine deoxycholate medium (Oxoid Ltd., Basingstoke, Hampshire, UK), and chromogenic medium Rambach (RA, Merck KGaA, Darmstadt, Germany) were used $\left(37^{\circ} \mathrm{C}\right.$ for $\left.24 \mathrm{~h}\right)$.

To determine the presence of Campylobacter spp. in $25 \mathrm{~g}$ a rapid serological test Singlepath Campylobacter (Merck KGaA, Darmstadt, Germany) was used. For incubation the Bolton broth medium (Oxoid Ltd., Basingstoke, Hampshire, UK) in a microaerophilic atmosphere $\left(5 \% \mathrm{O}_{2}, 10 \% \mathrm{CO}_{2}\right.$ and $\left.85 \% \mathrm{~N}_{2}\right)$ initially at $32{ }^{\circ} \mathrm{C}$ for $4 \mathrm{~h}$ was used and then at $41.5^{\circ} \mathrm{C}$ for $44 \mathrm{~h}$.

PCA (Plate Count Agar) medium (Oxoid Ltd., Basingstoke, Hampshire, UK) at $30{ }^{\circ} \mathrm{C}$ for $48 \mathrm{~h}$ was used to evaluate the number of the total viable counts (TVC).

For the mesophilic lactic acid bacteria counts and the determination of the MRS (Man Rogosa Sharpe) agar medium (Merck KGaA, Darmstadt, Germany) at $30{ }^{\circ} \mathrm{C}$ for $48 \mathrm{~h}$ was used.

Escherichia coli counts was determined using agar TBX (Tryptone Bile X-Glucuronide) medium (Oxoid Ltd., Basingstoke, Hampshire, UK) with incubation at $44^{\circ} \mathrm{C}$ for $18-24 \mathrm{~h}$.

To determine the Enterobacteriaceae counts VRBD (Violet Red Bile Glucose) agar medium (Merck KGaA, Darmstadt, Germany) at $37^{\circ} \mathrm{C}$ for $24 \mathrm{~h}$ was used.

The positive coagulase Staphylococcus enumeration was performed on RPF (Rabbit Plasma Fibrinogen) medium (Oxoid Ltd., Basingstoke, Hampshire, UK) at $37^{\circ} \mathrm{C}$ for $18-24 \mathrm{~h}$.

The number of bacteria was expressed as $\log 10$ of colony forming units per gram of MSPM $(\log \mathrm{cfu} / \mathrm{g})$. In the case of E. coli and coagulase positive Staphylococcus if their presence was not confirmed in the sausage after production and 1 week of storage they were not determined after 3 weeks of refrigerated storage. In the case of Salmonella spp. and Campylobacter spp., if their presence was not confirmed in the sausage after production they were not determined in the further research stages during refrigerated storage. The remaining microbiological tests were performed on the products after production and also after 1 and 3 weeks of storage at $4{ }^{\circ} \mathrm{C}$. 


\subsection{Biochemical Identification of $L A B$}

The sausage samples were inoculated on plates with MRS agar as described above. After incubation the cultures were taken randomly, 10 colonies per each sample and placed in the MRS broth (LabM, Heywood, UK). Identification of isolated bacteria strains whether or not they belonged to the Lactobacillus genus was confirmed by Grama staining and by observing cells under a microscope as well as by a catalase test. Species identification was performed using an API CHL50 test (bioMérieux Polska Sp. z o.o, Warsaw, Poland) according to the producers' manual. Biochemical profiles obtained as carbohydrates fermentation results interpreted with an apiwebTM base allowed to qualify the tested isolates to the species. Next, they were compared to the L. plantarum SCH1 strain profile used within the experiment.

\subsection{Sensory Assessment}

The sensory assessment was performed using a Quantitative Descriptive Profile (QDP) method according to the ISO 13299:2016 norm. The assessing teams' task was to determine the intensity of each of the mentioned quality traits and to put their own assessment on the adequate non-structured graphic scale (0-10). In order to compare the sensory quality of the model meat products in the sensory assessment after production, the following parameters were used: four taste discriminants (of cured meat, acidic, fatty, salty, where 0 - the least intense, 10-the most intense), three flavor determinants (of cured meat, acidic/spicy, fatty, where 0 - the least intense, 10-the most intense) also the following traits were estimated: flavor desirability, color tone, tenderness, juiciness, taste desirability, general quality, where 0 - the least desirable, 10 - the most desirable. In order to compare the sensory quality of the model meat products after 3 weeks of cold storage the following was applied: two flavor discriminants (smoked, fatty, where 0-the least intense, 10the most intense) and the following traits were assessed: flavor desirability, color tone, tenderness, taste desirability, general quality where 0 - the least desirable, 10 - the most desirable. The sensory assessment of the sausages after 3 weeks of cold storage was limited to seven discriminants due to the unacceptable taste and flavor of the control treatment of the product. Samples before assessment were stored in a room with $24 \pm 1{ }^{\circ} \mathrm{C}$ for $30 \mathrm{~min}$. Each time the assessing team obtained samples of the MSPM sausages, coded with a three-digit code, in the plastic $250 \mathrm{~mL}$ container with a lid, a dish with water for mouth rinsing and the assessment card. There were two slices of sausage; each slice was from a different sausage bar, in each container. The assessment was performed by a trained team of eight people and conducted in the sensory analysis studio with individual stands for assessors with artificial lighting. The sensory quality assessment of the model products was performed after production and after 3 weeks of storage.

\subsection{Statistical Analysis}

All the experiments were performed in triplicates in the independent trials (replicates) $n=3$ and a completely randomized design were used. A one-way analysis of variance (ANOVA) was applied, first between treatments and then between the storage time of the samples for all parameters. Means and standard deviations were calculated and a probability level of $p<0.05$ was used in testing the statistical significance of all of the experimental data. The Fisher test was used to determine the significance of the mean values for a multiple comparison $(p<0.05)$. Data analyses were conducted using the STATGRAPHICS v. 4.1 statistical program (Manugistics Inc., Rockville, MD, USA).

\section{Results and Discussion}

\subsection{Determination of $p H$}

In the control treatment the $\mathrm{pH}$ increase was observed during the whole storage period $(p<0.05)$. In the $\mathrm{L}$ treatment the $\mathrm{pH}$ value increase was observed only after 3 weeks of storage $(p<0.05)$. The slight $\mathrm{pH}$ value increase after 3 weeks of cold storage could be 
the result of hydrolysis protein transformations that run in the heat treated product and microorganisms enzymes activity [32].

During the whole storage period, no differences $(p>0.05)$ in the $\mathrm{pH}$ values between the treatments were observed (Table 2). No differences in the samples acidity after production indicated similar $\mathrm{pH}$ changes in the dynamics of the raw MSPM during 4 days of cold storage $\left(4{ }^{\circ} \mathrm{C}\right)$. In previous research this fact was also confirmed [24]. Relatively low sugar content in the MSPM could have an influence on the limited production of various metabolites including lactic acid by using LAB [33]. In the research of Vermeiren et al. [34] either the differences in acidity were not observed between cured cooked ham inoculated with L. plantarum (after cooking) and the sample without bacteria after 13 days of cold storage. The correlation between the amount of sugars in the medium and the level of the products acidification was also confirmed.

Table 2. $\mathrm{pH}$ and ORP changes (mean $\pm \mathrm{SD}$ ) in sausages with MSPM during storage.

\begin{tabular}{ccccc}
\hline \multirow{2}{*}{ Parameter } & Treatment & \multicolumn{3}{c}{ Storage Time (Weeks) } \\
\cline { 3 - 5 } & & $\mathbf{0}$ & $\mathbf{1}$ & $\mathbf{3}$ \\
\hline \multirow{2}{*}{$\mathrm{pH}$} & $\mathrm{C}$ & $6.72 \pm 0.01^{\mathrm{aA}}$ & $6.76 \pm 0.02^{\mathrm{aB}}$ & $6.80 \pm 0.01^{\mathrm{aC}}$ \\
& $\mathrm{L}$ & $6.74 \pm 0.02^{\mathrm{aAB}}$ & $6.72 \pm 0.02^{\mathrm{aA}}$ & $6.78 \pm 0.02^{\mathrm{aB}}$ \\
$\mathrm{ORP}(\mathrm{mV})$ & $\mathrm{C}$ & $284.3 \pm 3.0^{\mathrm{bA}}$ & $332.2 \pm 4.0^{\mathrm{bB}}$ & $331.7 \pm 2.5^{\mathrm{bB}}$ \\
& $\mathrm{L}$ & $271.5 \pm 2.9^{\mathrm{aA}}$ & $322.4 \pm 2.3^{\mathrm{aC}}$ & $311.6 \pm 2.8^{\mathrm{aB}}$
\end{tabular}

C-control treatment with MSPM without a bacteria strain, L-treatment with MSPM and the bacteria L. plantarum $\mathrm{SCH} 1\left(10^{7} \mathrm{cfu} / \mathrm{g}\right)$. Various small letters $(\mathrm{a}-\mathrm{b})$ in the same column indicate significant differences between treatments $(p<0.05)$. Various capital letters $(\mathrm{A}-\mathrm{C})$ in the same line indicate significant differences while being stored $(p<0.05)$.

\subsection{Oxidative-Reduction Potential}

In both sausage treatments the increase $(p<0.05)$ of redox potential was observed during storage (Table 2). During the whole storage period a significantly higher $(p<0.05)$ redox value was observed in the $\mathrm{C}$ treatment, which means that adding L. plantarum SCH1 could inhibit the oxidation processes in the final product. Fine grinding, tissue structure decay, and aeration during the separation process caused the MSPM to be more prone to oxidation [6]. LAB belongs to organisms relatively anaerobic but in unfavorable conditions they might use oxygen as a final electrons acceptor. Nevertheless, oxygen might have a negative effect on the lactic acid bacteria cells. During oxygen reduction in the respiratory chain they appear damaging for the cells hydroxyl radicals, hydrogen peroxide and peroxide radicals. Reactive oxygen species (ROS) attack proteins, lipids and nucleic acids contribute directly to cells' death $[35,36]$ Some LAB respond to oxygen stress with increased anti-oxidative enzymes synthesis [37]. In the case of L. plantarum the pseudocatalse containing manganese is produced (manganese-containing catalase) [38]. The other enzyme catalyzing hydrogen peroxide decomposition is glutathione peroxidase [39]. Moreover, the activity of the L. plantarum SCH1 anti-oxidative enzymes in raw MSPM batter during cold storage before cooking could have an influence on the redox potential value in the product after thermal treatment.

The highest redox potential in the $C$ and $L$ treatments was observed 1 week after storage. After 3 weeks of storage, the redox potential in the $C$ treatment was similar $(331.7 \mathrm{mV})$, but in sausage with the addition of L. plantarum SCH1 the redox potential was significantly lower $(p<0.05)$ and lowered from $322.4 \mathrm{mV}$ to $311.6 \mathrm{mV}$. It should be pointed out that the significant anti-oxidative activity of L. plantarum SCH1 in the L treatment after 3 weeks of storage could have an effect on lower redox potential in this period [37].

\subsection{Total Heme Pigments Content and Nitrosyl Myoglobin Concentration}

The total heme pigments content did not differ significantly $(p>0.05)$ between the sausages with MSPM during storage (Table 3). After production the total heme pigments content reached $113.56 \mathrm{ppm}$ in the $\mathrm{C}$ treatment and $116.51 \mathrm{ppm}$ in the L treatment and 
after 3 weeks of storage was $114.01 \mathrm{ppm}$ and $112.20 \mathrm{ppm}$, respectively. In the treatment with L. plantarum SCH1, the heme pigments contents lowered significantly $(p<0.05)$ after 3 weeks of cold storage compared to their level after production (Table 3). Taking into consideration the fact that, after 3 weeks of cold storage, lactic acid bacteria were present in the sausages it may be assumed that they used heme from the meat environment for their growth. Abriouel et al. [40] found that L. plantarum CNRZ 1228 showed heme depended on catalysis activity on MRS broth with $30 \mathrm{mM}$ hematin, whereas only on the MRS base it did not show any activity of this enzyme. heme delivered from the environment influences the faster growth of L. plantarum and enables longer bacteria life [41].

Table 3. Nitrite and nitrate (mean $\pm \mathrm{SD}$ ), total heme pigments (mean $\pm \mathrm{SD}$ ) and nitrosyl myoglobin content (mean \pm SD) changes in the model sausages with MSPM during storage.

\begin{tabular}{ccccc}
\hline \multirow{2}{*}{ Parameter } & Treatment & \multicolumn{3}{c}{ Storage Time (Weeks) } \\
\cline { 3 - 5 } & & $\mathbf{0}$ & $\mathbf{1}$ & 1 \\
\hline Nitrite $(\mathrm{mg} / \mathrm{kg})$ & $\mathrm{C}$ & $16.5 \pm 0.2^{\mathrm{aC}}$ & $15.4 \pm 0.1^{\mathrm{aB}}$ & $14.4 \pm 0.1^{\mathrm{aA}}$ \\
Nitrate $(\mathrm{mg} / \mathrm{kg})$ & $\mathrm{L}$ & $16.8 \pm 0.2^{\mathrm{aC}}$ & $15.7 \pm 0.1^{\mathrm{aB}}$ & $14.4 \pm 0.3^{\mathrm{aA}}$ \\
& $\mathrm{C}$ & $62.2 \pm 4.9^{\mathrm{aB}}$ & $49.1 \pm 0.8^{\mathrm{aA}}$ & $65.4 \pm 2.4^{\mathrm{aB}}$ \\
Total heme pigments content & $\mathrm{L}$ & $66.4 \pm 3.0^{\mathrm{aB}}$ & $49.3 \pm 1.1^{\mathrm{aA}}$ & $67.1^{\mathrm{aB}} \pm 0.6^{\mathrm{aB}}$ \\
(ppm) & $\mathrm{C}$ & $113.56 \pm 0.68^{\mathrm{aB}}$ & $110.84 \pm 1.18^{\mathrm{aA}}$ & $114.01 \pm 0.39^{\mathrm{aB}}$ \\
NOMb content $(\mathrm{g} / 100 \mathrm{~g})$ & $\mathrm{L}$ & $116.51 \pm 1.96^{\mathrm{aB}}$ & $109.48 \pm 0.68^{\mathrm{aA}}$ & $112.20 \pm 1.80^{\mathrm{aA}}$ \\
& $\mathrm{C}$ & $75.93 \pm 1.52^{\mathrm{bB}}$ & $78.84 \pm 1.04^{\mathrm{aB}}$ & $58.93 \pm 2.73^{\mathrm{aA}}$ \\
\hline
\end{tabular}

C-control treatment with MSPM without a bacteria strain, L-treatment with MSPM and the bacteria L. plantarum SCH1 (10 $\left.{ }^{7} \mathrm{cfu} / \mathrm{g}\right)$. Various small letters $(\mathrm{a}-\mathrm{b})$ in the same column indicate significant differences between treatments $(p<0.05)$. Various capital letters $(\mathrm{A}-\mathrm{C})$ in the same line indicate significant differences while being stored $(p<0.05)$.

The $C$ treatment after production was of significantly higher nitrosyl myoglobin $(\mathrm{NOMb})$ concentration $(p<0.05)$. Lower $\mathrm{NOMb}$ content in the $\mathrm{L}$ treatment after production could be due to the negative effect of $\mathrm{H}_{2} \mathrm{O}_{2}$ produced by $\mathrm{LAB}$ on nitrosyl heme pigments in MSM batter [40]. After 3 weeks of storage, the tendency was the reverse. A significantly higher $(p<0.05) \mathrm{NOMb}$ concentration level was found in the $\mathrm{L}$ treatment where L. plantarum SCH1 was applied (Table 3).

Significantly lower redox potential in the $\mathrm{L}$ treatment and in consequence higher environmental reductivity probably caused a higher nitrosyl pigment level in the $\mathrm{L}$ treatment after 3 weeks of storage compared to the control treatment (C) [42]. In both experimental sausages, the concentration of nitrosyl pigments after 3 weeks of storage was lower compared to the concentration determined after production. Reduced nitrosyl pigment levels in the meat products during storage is a commonly known fact and is caused by nitrosyl myochromogen oxidation [43].

\subsection{Nitrates and Nitrites Content}

The dynamics of nitrates and nitrites transformation in meat products during storage depends on many parameters including environment acidity, redox potential, and the amount of reducing substances [44]. In both experimental sausages a statistically significant $(p<0.05)$ reduction of nitrites level during storage was observed. No differences $(p>0.05)$ in $\mathrm{NO}_{2}$ content was observed between the treatments during cold storage (Table 3 ). In the research of Terns et al. [45], the decrease of nitrites level was observed in cured pork sausages during 84 days of cold storage. Similar results were reported by Shin et al. [46] in the case of cured pork pates after 28 days of cold storage. Nitrites reduction in batters and meat products is connected with the reaction of these compounds with muscle and fat tissue components as well as with additional substances introduced into the meat batters [47].

The amount of nitrates in the sausages after production was similar and reached $62.2 \mathrm{mg} / \mathrm{kg}$ in the $\mathrm{C}$ treatment and $66.4 \mathrm{mg} / \mathrm{kg}$ in the $\mathrm{L}$ treatment. The amount of nitrates 
decreased after 1 week of storage to approx. $49 \mathrm{mg} / \mathrm{kg}$ in both of the experimental sausages. Next, the significant increase of nitrates content was observed to the level of $65.4 \mathrm{mg} / \mathrm{kg}$ and $67.1 \mathrm{mg} / \mathrm{kg}$ respectively in treatment $C$ and 7 after 3 weeks of storage $(p<0.05)$. Nitrates reduction in the tested meat products could be performed with the participation of bacterial enzymes. Whereas the observed nitrates increase in the products was probably caused by the transformation of residual nitrites during cold storage [42]. The introduction of lactic acid bacteria did not have a significant effect $(p>0.05)$ on nitrites and nitrates level in the L treatment (Table 3).

\subsection{Color}

The values of $\mathrm{a}^{*}$ and $\mathrm{b}^{*}$ parameters in the model products after production and after storage were similar and did not differ significantly $(p>0.05)$. Statistically significant differences $(p<0.05)$ were observed in the color lightness parameter $\left(L^{*}\right)$ in both treatments after storage. The lowest $L^{*}$ parameter values were observed 1 week after storage reaching 57.74 in the $C$ treatment and 58.15 in the $\mathrm{L}$ treatment. A similar result was reported by Slima et al. [48], who observed color lightness decrease after 10 days in the storage of cured $(50 \mathrm{mg} / \mathrm{kg}$ ) raw beef sausages without significant differences between the control sample (without bacteria) and the sample with L. plantarum. The highest share of the red color $\left(\mathrm{a}^{*}\right)$ was reported in the $\mathrm{C}$ and $\mathrm{L}$ treatments directly after production reaching 17.33 and 17.22 , respectively (Table 4).

Table 4. Color parameters (mean \pm SD) in the model sausages with MSPM during storage.

\begin{tabular}{ccccc}
\hline \multirow{2}{*}{ Parameter } & Treatment & \multicolumn{3}{c}{ Storage Time (Weeks) } \\
\cline { 3 - 5 } & & $\mathbf{0}$ & $\mathbf{1}$ & $\mathbf{3}$ \\
\hline $\mathrm{L}^{*}$ & $\mathrm{C}$ & $58.43 \pm 0.75^{\mathrm{aB}}$ & $57.74 \pm 0.63^{\mathrm{aA}}$ & $58.30 \pm 0.31^{\mathrm{aAB}}$ \\
& $\mathrm{L}$ & $58.82 \pm 0.48^{\mathrm{aB}}$ & $58.15 \pm 0.35^{\mathrm{aA}}$ & $58.41 \pm 0.39^{\mathrm{aAB}}$ \\
$\mathrm{a}^{*}$ & $\mathrm{C}$ & $17.33 \pm 0.52^{\mathrm{aA}}$ & $16.93 \pm 0.38^{\mathrm{aA}}$ & $17.15 \pm 0.36^{\mathrm{AA}}$ \\
& $\mathrm{L}$ & $17.22 \pm 0.83^{\mathrm{aA}}$ & $17.09 \pm 0.29^{\mathrm{aA}}$ & $17.12 \pm 0.33^{\mathrm{aA}}$ \\
$\mathrm{b}^{*}$ & $\mathrm{C}$ & $5.26 \pm 0.22^{\mathrm{aA}}$ & $5.49 \pm 0.22^{\mathrm{aB}}$ & $5.43 \pm 0.18^{\mathrm{aAB}}$ \\
& $\mathrm{L}$ & $5.36 \pm 0.25^{\mathrm{aA}}$ & $5.39 \pm 0.15^{\mathrm{aA}}$ & $5.48 \pm 0.09^{\mathrm{aA}}$ \\
$\mathrm{a}^{*} / \mathrm{b}^{*}$ & $\mathrm{C}$ & $3.30 \pm 0.17^{\mathrm{aB}}$ & $3.09 \pm 0.13^{\mathrm{aA}}$ & $3.16 \pm 0.11^{\mathrm{aA}}$ \\
& $\mathrm{L}$ & $3.22 \pm 0.23^{\mathrm{aA}}$ & $3.17 \pm 0.09^{\mathrm{aA}}$ & $3.13 \pm 0.08^{\mathrm{aA}}$ \\
\hline
\end{tabular}

C-control treatment with MSPM without a bacteria strain; L-treatment with MSPM and the bacteria L. plantarum SCH1 $\left(10^{7} \mathrm{cfu} / \mathrm{g}\right)$. Various small letters $(\mathrm{a}-\mathrm{b})$ in the same column indicate significant differences between treatments $(p<0.05)$. Various capital letters $(\mathrm{A}-\mathrm{B})$ in the same line indicate significant differences while storing $(p<0.05)$.

The $b^{*}$ parameter value was similar in both experimental treatments in the whole storage period and ranged between 5.26 and 5.49 . A significant decrease of the $\mathrm{a}^{*} / \mathrm{b}^{*}$ factor was observed in the $C$ treatment after storage which indicated a lower share of red color in the products [31] (Table 4). A lower share of red color in the $C$ treatment might have been caused by the significant increase of redox potential and by NOMb concentration decrease in this sample after storage [42,49] (Table 3).

\subsection{Microbiological Quality}

Total viable counts (TVC) after production in the $\mathrm{C}$ treatment reached $2.16 \log \mathrm{cfu} / \mathrm{g}$ and was significantly lower $(p<0.05)$ than in the L treatment $(2.51 \log \mathrm{cfu} / \mathrm{g})$. After 1 week of storage TVC was at a similar level and reached $2.19 \mathrm{log} \mathrm{cfu} / \mathrm{g}$ in the $\mathrm{C}$ treatment and $2.54 \log \mathrm{cfu} / \mathrm{g}$ in the L treatment (Table 5). In the research of Zeleňáková, Kunová, and Lopašovský [50] TVC was determined in cooked pork sausages at the level of approx. $4 \mathrm{log} \mathrm{cfu} / \mathrm{g}$. Similar TVC values after production (4.05 log cfu/g) and after 3 weeks of storage (4.64 log cfu/g) was observed in the research of Eskandari et al. [51] in frankfurtertype sausages with low additive $\mathrm{NaNO}_{2}(40 \mathrm{ppm})$ during refrigerated storage at $4{ }^{\circ} \mathrm{C}$. 
Table 5. Microbiological quality (mean \pm SD) of the model sausages with MSPM during storage.

\begin{tabular}{|c|c|c|c|c|}
\hline \multirow{2}{*}{ Parameter } & \multirow{2}{*}{ Treatment } & \multicolumn{3}{|c|}{ Storage Time (Weeks) } \\
\hline & & 0 & 1 & 3 \\
\hline \multirow{2}{*}{ Total viable counts (log cfu/g) } & $\mathrm{C}$ & $2.16 \pm 1.06^{\mathrm{aA}}$ & $2.19 \pm 0.76^{\mathrm{aA}}$ & $8.24 \pm 7.06^{\mathrm{bB}}$ \\
\hline & $\mathrm{L}$ & $2.51 \pm 1.48^{\mathrm{bA}}$ & $2.54 \pm 1.06^{\mathrm{bA}}$ & $7.31 \pm 5.76^{\mathrm{aB}}$ \\
\hline \multirow{2}{*}{ Lactic acid bacteria counts (log cfu/g) } & $\mathrm{C}$ & $<1.00$ & $<1.00$ & $5.23 \pm 4.00^{\mathrm{a}}$ \\
\hline & $\mathrm{L}$ & $<1.00$ & $<1.00$ & $5.92 \pm 4.64^{b}$ \\
\hline \multirow{2}{*}{ Escherichia coli counts (log cfu/g) } & $\mathrm{C}$ & $<1.00$ & $<1.00$ & na \\
\hline & $\mathrm{L}$ & $<1.00$ & $<1.00$ & na \\
\hline \multirow{2}{*}{ Enterobacteriaceae counts (log cfu/g) } & $\mathrm{C}$ & $<1.00$ & $<1.00$ & $<1.00$ \\
\hline & $\mathrm{L}$ & $<1.00$ & $<1.00$ & $<1.00$ \\
\hline \multirow{2}{*}{$\begin{array}{l}\text { Coagulase-positive Staphylococcus count } \\
\qquad(\log \mathrm{cfu} / \mathrm{g})\end{array}$} & $\mathrm{C}$ & $<1.00$ & $<1.00$ & na \\
\hline & $\mathrm{L}$ & $<1.00$ & $<1.00$ & na \\
\hline \multirow{2}{*}{ Salmonella sp. content in $25 \mathrm{~g}$} & $\mathrm{C}$ & nd & na & na \\
\hline & $\mathrm{L}$ & nd & na & na \\
\hline \multirow{2}{*}{ Campylobacter spp. content in $25 \mathrm{~g}$} & $\mathrm{C}$ & nd & na & na \\
\hline & $\mathrm{L}$ & nd & na & na \\
\hline
\end{tabular}

C—control treatment with MSPM without a bacteria strain, L-treatment with MSPM and the bacteria L. plantarum SCH1 (10 $\mathrm{cfu} / \mathrm{g})$. Various small letters $(\mathrm{a}-\mathrm{b})$ in the same column indicate significant differences between treatments $(p<0.05)$. Various capital letters (A-B) in the same line indicate significant differences while storing $(p<0.05)$; na-not applicable, nd-not detected.

In sausages after production no Salmonella sp. nor Campylobacter spp. was confirmed. Counts of Enterobacteriaceae, E. coli, coagulase positive Staphylococcus, and LAB after production were $<1 \log \mathrm{cfu} / \mathrm{g}$, which means that the heat dose used in the products thermal treatment effectively reduced their number. After 1 week of cold storage the microbiological quality of the sausages did not change (Table 5).

After 3 weeks of storage, the microbiological quality of the sausages changed. The total viable counts increased significantly in both treatments and the increase of mesophilic lactic acid bacteria was observed (Table 5). The TVC in the control C treatment $(8.24 \mathrm{log} \mathrm{cfu} / \mathrm{g})$ was significantly higher than in the $\mathrm{L}$ treatment $(7.31 \mathrm{log} \mathrm{cfu} / \mathrm{g})$; it might prove that the bacteria strain applied inhibited the growth of undesirable microflora. Reverse dependence was observed in the case of lactic acid bacteria. In the control treatment (C), a significantly lower $(p<0.05)$ LAB level was reported $(5.23 \mathrm{log} \mathrm{cfu} / \mathrm{g})$ than in the L treatment (5.92 log cfu/g).

The TVC in the control $C$ treatment $(8.24 \log \mathrm{cfu} / \mathrm{g})$ was significantly higher than in the $\mathrm{L}$ treatment $(7.31 \log \mathrm{cfu} / \mathrm{g})$; it might prove that the bacteria strain applied inhibited the growth of undesirable microflora. Reverse dependence was observed in the case of lactic acid bacteria. In the control $C$ treatment a significantly lower $(p<0.05)$ LAB level was reported $(5.23 \log \mathrm{cfu} / \mathrm{g})$ than in the L treatment $(5.92 \mathrm{log} \mathrm{cfu} / \mathrm{g})$. The high level of TVC in both samples could be due to the increase in LAB also in the TVC cultivation, which is confirmed by the studies of other authors [52,53]. Lactic acid bacteria (LAB) are facultative anaerobic and are regarded as a specific spoilage organism in vacuum-packaged cooked meat products during long-term storage, probably due to its dominance in the total viable microflora as well as heat-resistance [54].

It may be assumed that the LAB level increase in the model products with MSPM at the early stage of storage was impeded due to bacterial cell damage caused by heat during thermal treatment. In the standard bacteria cultivation technique, only replicating cells are determined. Roszak et al. [55] showed that cells might enter a dormant state when the environmental conditions become unfavorable (lack of nutrients, temperature, and $\mathrm{pH}$ changes). VBNC (viable but nonculturable) cells exhibit active metabolism in the form of respiration or fermentation, incorporate radioactive substrates, and have active protein synthesis but cannot be cultured or grown on conventional laboratory media. The dormancy state is temporary and bacteria cells might reactivate the ability to replicate by corrective mechanisms [56-58], which was most probably observed after 3 weeks of storage. This hypothesis could be confirmed by flow cytometry, but in our study isolation 
and identification by preliminary phenotypic and biochemical research were conducted (Table 6). It was found that bacteria isolated from the sausages was in the majority of bacilli, Gram-positive, catalase-negative. In the case of experimental treatment $\mathrm{C}-4$ out of 10 isolates were excluded from further research whereas in the L treatment 1 isolate was excluded due to being atypical for the Lactobacillus cells shape.

Table 6. Biochemical estimation results of isolates.

\begin{tabular}{|c|c|c|c|c|}
\hline Treatment & Isolate & Bacteria Type & $\begin{array}{c}\text { Number of True Tests of } \\
\text { Isolate Biochemical } \\
\text { Activity with SCH1 } \\
\text { Strain }\end{array}$ & Bacteria Species \\
\hline \multirow{10}{*}{$\mathrm{C}$} & 1 & Lactobacillus & $40 / 49$ & paracasei \\
\hline & 2 & $\mathrm{nb}$ & na & na \\
\hline & 3 & $\mathrm{nb}$ & na & na \\
\hline & 4 & Lactobacillus & $41 / 49$ & pentosus \\
\hline & 5 & Lactobacillus & $48 / 49$ & plantarum \\
\hline & 6 & $\mathrm{nb}$ & na & na \\
\hline & 7 & Lactobacillus & $45 / 49$ & brevis \\
\hline & 8 & $\mathrm{nb}$ & na & na \\
\hline & 9 & Lactobacillus & $45 / 49$ & brevis \\
\hline & 10 & Lactobacillus & $41 / 49$ & pentosus \\
\hline \multirow{10}{*}{$\mathrm{L}$} & 1 & Lactobacillus & $45 / 49$ & plantarum \\
\hline & 2 & Lactobacillus & $42 / 49$ & rhamnosus \\
\hline & 3 & Lactobacillus & $49 / 49$ & plantarum \\
\hline & 4 & $\mathrm{nb}$ & na & na \\
\hline & 5 & Lactobacillus & $29 / 49$ & buchneri \\
\hline & 6 & Lactobacillus & $48 / 49$ & plantarum \\
\hline & 7 & Lactobacillus & $49 / 49$ & plantarum \\
\hline & 8 & Lactobacillus & $49 / 49$ & plantarum \\
\hline & 9 & Lactobacillus & $48 / 49$ & plantarum \\
\hline & 10 & Lactobacillus & $42 / 49$ & rhamnosus \\
\hline
\end{tabular}

Bacteria isolates were preliminarily attributed to the genus Lactobacillus according the appearance under the microscope, Gram staining and test for catalase, and next the species was identified using a set of 49 biochemical tests (Table 6). It was proved that, in the case of control treatment (C), only one isolate was in compliance with the biochemical activity profile of the SCH1 strain but in the case of the L treatment six isolates complied with the plantarum species (Table 6).

Slight differences in the biochemical profiles of isolates might be a sign that bacteria is in a lag phase accommodating to external environmental conditions, expressing or repressing genes responsible for certain traits $[57,58]$. However, it is clear that molecular biology techniques for identification, considered as the most precise ones, are recommended due to the confirmation of the results. In this study, our goal was to initially confirm the presence of Lactobacillus bacteria in the samples and to exclude the presence of other, e.g., spore-forming bacteria that could grow on MRS agar. The present results of the conducted research indicate that the L. plantarum bacteria specie has been confirmed in the L treatment. In addition, our previous studies have also shown that the meat environment is suitable for L. plantarum SCH1 bacterial growth $[25,28]$, which is in agreement with the present results of research.

The use of nitrites in preserving meat products plays a key role in inhibiting Clostridium botulinium bacteria growth and preventing the production of botulinum toxins $[44,59,60]$. In this study, we did not analyze the antimicrobial efficacies of using of L. plantarum SCH1 and sodium nitrite in a reduced amount $(50 \mathrm{mg} / \mathrm{kg})$ against $C$. botulinum. However, the properties of curing with nitrite that also make it an effective antibotulinal compound are dependent on the interactions of nitrite with several other factors (salt, $\mathrm{pH}$, heat 
treatment, spore level, ingoing nitrite level during manufacture, and residual nitrite levels in the meat) [60,61]. Lövenklev et al. [62] indicated that use of $\mathrm{NaNO}_{2}$ at $45.0 \mathrm{mg} / \mathrm{kg}$ effectively suppresses $C$. botulinium gene expression. Also other research proved applying $\mathrm{NaNO}_{2}$ at $37.5 \mathrm{mg} / \mathrm{kg}$ or $75.0 \mathrm{mg} / \mathrm{kg}$ together with $\mathrm{NaCl}$ to the amount of $2.5 \%$ completely inhibits the growth of C. botulinium in an anaerobic environment [63].

\subsection{Sensory Quality}

After the production process the sensory quality of the MSPM sausages was at a similar level and no significant differences between the treatments were observed $(p>0.05)$. Using lactic acid bacteria did not have a significant $(p>0.05)$ effect on product taste and flavor desirability nor on the remaining sausage sensory traits assessed directly after production (Figure 1).

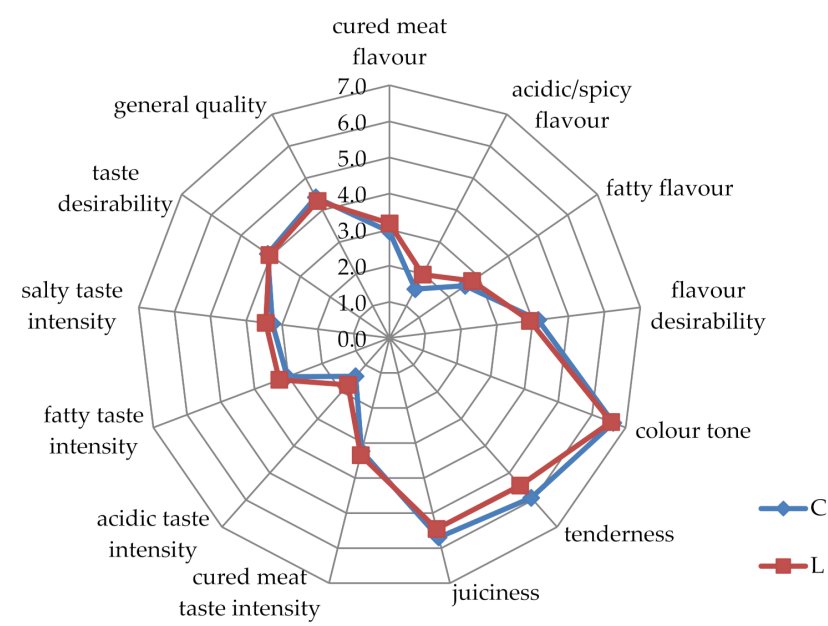

Figure 1. Sensory evaluation of MSPM sausages after production. C-control treatment with MSPM without a bacteria strain, L-treatment with MSPM and the bacteria L. plantarum SCH1 $\left(10^{7} \mathrm{cfu} / \mathrm{g}\right)$; No significant statistical differences were found $(p>0.05)$.

Interesting research results were obtained in terms of sausage sensory traits 3 weeks after storage. In the control treatment sensory assessment showed features proving that the product was spoiled. That is why, after 3 weeks of cold storage, only chosen indicators of sausage flavor and consistency as well as general desirability were assessed (Figure 2).

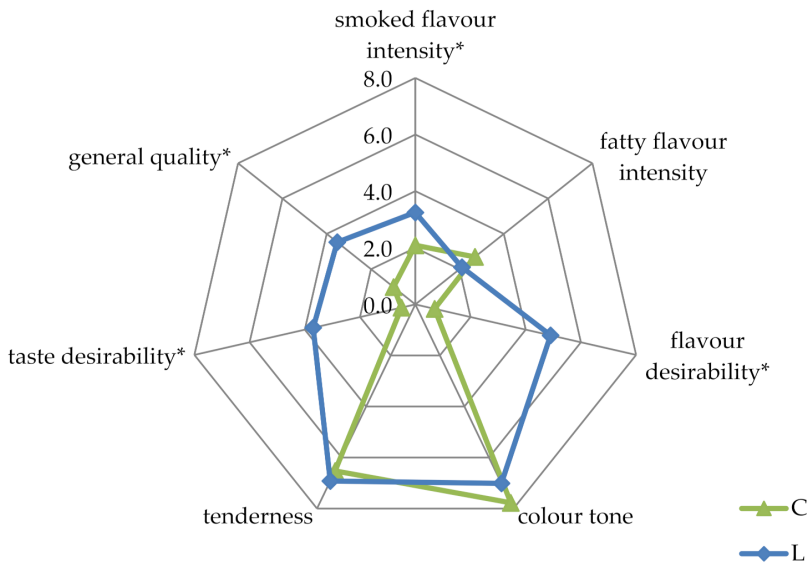

Figure 2. Sensory evaluation of MSPM sausages after 3 weeks of refrigerated storage. C-control treatment with MSPM without a bacteria strain, L-treatment with MSPM and the bacteria $L$. plantarum SCH1 $\left(10^{7} \mathrm{cfu} / \mathrm{g}\right){ }^{*}$ Mean values of this attribute are significantly different $(p<0.05)$. 
In the case of the sausage enriched with the L. plantarum SCH1 strain, no sensory disqualifying traits were found in the product. L sausage taste and flavor was of high desirability (Figure 2). In the research of Vermeiren et al. [34] assessed cured cooked ham products with L. plantarum addition (spread on the surface of slices) were rejected by the sensory panel after 13 days of storage due to the unacceptable taste. LAB addition, like in the tested MSPM sausages in this research, did not have an effect on the color and general appearance of the cured cooked ham products. Pérez-Chabela et al. [26] reported higher scores in the sensory tests of sausages with L. plantarum compared to the control treatment $(p<0.05)$. Whereas Victoria-León et al. [25] observed taste improvement and overall acceptance improvement in sausages with L. lactis and L. piscicola after thermal treatment (inoculated before scalding) after 2 days of cold storage. After 12 days of cold storage, sausages with the LAB addition obtained lower scores compared to the control sample.

\section{Conclusions}

The performed studies indicated the possibility of using L. plantarum SCH1 for the biopreservation of cooked sausages with MSPM cured with a lower sodium nitrite dose. The microbiological analysis and sensory assessment of MSPM sausages showed the protective activity of L. plantarum SCH1 against undesirable microorganisms causing product spoilage. No negative effect of L. plantarum SCH1 on the physical and chemical model sausages parameters after production and after storage was observed. Nevertheless, the study must be continued, especially in terms of analyzing the antimicrobial efficacies of using L. plantarum SCH1 and sodium nitrite in a reduced amount against microorganisms causing product spoilage and pathogens, including Clostridium botulinum. Further research will also embrace more detailed molecular identification tests of $L$. plantarum SCH1 bacteria applied to heat-treated meat products.

Author Contributions: Conceptualization, B.Ł., P.S., and D.K.-K.; Formal analysis, B.Ł., P.S., and D.K.-K.; Methodology, B.Ł. and D.Z.; Writing—original draft, B.Ł., P.S., and D.Z.; Writing-review and editing, B.E., P.S., D.Z., and D.K.-K. All authors have read and agreed to the published version of the manuscript.

Funding: This research received no external funding.

Institutional Review Board Statement: Not applicable.

Informed Consent Statement: Not applicable.

Data Availability Statement: The data presented in this study are available on request from the corresponding author.

Conflicts of Interest: The authors declare no conflict of interest.

\section{References}

1. Froning, S.M.; McKee, G.F. Mechanical separation of poultry meat and its use in products. In Poultry Meat Processing, 1st ed.; Sams, A.R., Ed.; CRC Press: Boca Raton, FL, USA, 2001; Volume 14, pp. 243-254.

2. Eurostat. Farm production-Livestock and meat. In Agriculture, Forestry and Fishery Statistics; Cook, E., Ed.; Publications Office of the European Union: Luxembourg, 2019; pp. 52-57.

3. Stiebing, A. Separatorenfleisch im Kreuzfeuer der Kritik. Fleischwirtsch 2002, 82, 8.

4. Gill, C.O. Visible contamination on animals and carcasses and the microbiological condition of meat. J. Food Prot. 2004, 67, 413-419. [CrossRef]

5. Gill, C.O.; Landers, C. Proximate sources of bacteria on boneless loins prepared from routinely processed and detained carcasses at a pork packing plant. Int. J. Food Microbiol. 2004, 97, 171-178. [CrossRef] [PubMed]

6. Daros, F.G.; Masson, M.L.; Amico, S.C. The influence of the addition of mechanically deboned poultry meat on the rheological properties of sausage. J. Food Process. Eng. 2005, 68, 185-189. [CrossRef]

7. Michalski, M. Characteristic of basic chemical constitution of poultry meat obtained in mechanical deboning process. Rocz. Inst. Przem. Mięsn. Tt. 2006, 44, 67-72.

8. Ozkececi, R.B.; Karakaya, M.; Yilmaz, M.T.; Saricoban, C.; Ockerman, H.W. The effect of carcass part and packaging metod on the storage stability of mechanically deboned chicken meat. J. Muscle Foods 2008, 19, 288-301. [CrossRef] 
9. Viuda-Martos, M.; Fernández-López, J.; Pérez-Álvarez, J.A. Mechanical deboning. In Handbook of Meat and Meat Processing, 2nd ed.; Hui, Y., Ed.; CRC Press: Boca Raton, FL, USA, 2012; Volume 5, pp. 457-468.

10. Yuste, J.; Pla, R.; Capellas, M.; Mor-Mur, M. Application of high-pressure processing and nisin to mechanically recovered poultry meat for microbial decontamination. Food Control 2002, 13, 451-455. [CrossRef]

11. Pomykała, R.; Michalski, M. Microbiological quality of mechanically separated poultry meat. Acta Sci. Pol. Med. Vet. 2008, 7, 43-49.

12. Michalski, M. Calcium content in meat mechanically separated using the traditional (pressure) method and a technique that does not damage the bone structure. Rocz. Inst. Przem. Mięs Tt. 2009, 47, 77-81.

13. On, S.; Wong, T.L.; Hom, B.; Graham, C.; Paulin, S. Bacterial concentrations of poultry offal and in mechanically separated meat products at the processing plant. In New Zaeland: Food Safety Authority; MAF Technical Paper No: 2011/59; Ministry of Agriculture and Forestry: Wellington, New Zealand, 2011.

14. Regulation (EC) No 853/2004 of the European Parliament and of the Council of 29 April 2004 laying down specific hygiene rules for on the hygiene of foodstuffs. Off. J. Eur. Union 2004, L139, 55.

15. Thielke, S.; Lhaft, S.K.; Kühne, M. Effects of aging prior to freezing on poultry meat tenderness. Poult. Sci. 2005, 84, 607-612. [CrossRef]

16. Pegg, R.B.; Shahidi, F. The color of meat. In Nitrite Curing of Meat: The N-Nitrosamine Problem and Nitrite Alternatives, 1st ed.; Pegg, R.B., Shahidi, F., Eds.; Food \& Nutrition Press Inc.: Trumbull, CT, USA, 2000; Volume 3, pp. 23-66.

17. Drabik-Markiewicz, G.; Van den Maagdenberg, K.; De Mey, E.; Kowalska, T.; Paelinck, H. Influence of putrescine, cadaverine, spermidine or spermine on the formation of N-nitrosamine in heated cured pork meat. Food Chem. 2011, 126, 1539-1545. [CrossRef]

18. Herrmann, S.S.; Granby, K.; Duedahl-Olesen, L. Formation and mitigation of N-nitrosamines in nitrite preserved cooked sausages. Food Chem. 2015, 174, 516-526. [CrossRef]

19. European Commission Decision (EU) 2018/702 of 8 May 2018 concerning national provisions notified by Denmark on the addition of nitrite to certain meat products (notified under document C (2018) 2721). Off. J. Eur. Union 2018, L118, 7-15.

20. Hugas, M. Bacteriocinogenic lactic acid bacteria for the biopreservation of meat and meat products. Meat Sci. 1998, 49, 39-150. [CrossRef]

21. Metaxopoulos, J.; Mataragas, M.; Drosinos, E.H. Microbial interaction in cooked cured meat products under vacuum or modified atmosphere at $4{ }^{\circ} \mathrm{C}$. J. Appl. Microbiol. 2002, 93, 363-373. [CrossRef]

22. Ammor, M.S.; Mayo, B. Selection criteria for lactic acid bacteria to be used as functional starter cultures in dry sausage production: An update. Meat Sci. 2007, 76, 138-146. [CrossRef]

23. Rzepkowska, A.; Zielińska, D.; Ołdak, A.; Kołożyn-Krajewska, D. Organic whey as a source of Lactobacillus strains with selected technological and antimicrobial properties. Int. J. Food Sci. Technol. 2017, 52, 1983-1994. [CrossRef]

24. Łaszkiewicz, B.; Szymański, P.; Kołożyn-Krajewska, D. Impact of selected lactic acid bacteria strains on technological usability and microbiological quality of mechanically separated poultry meat. Żywn Nauk Technol. 2019, 26, 122-134.

25. Łaszkiewicz, B.; Szymański, P.; Kołożyn-Krajewska, D. The effect of selected lactic acid bacterial strains on the technological and microbiological quality of mechanically separated poultry meat cured with a reduced amount of sodium nitrite. Poult. Sci. 2020, in press.

26. Victoria-León, T.; Totosaus, A.; Guerrero, I.; Pérez-Chabela, M.L. Efecto de bacterias ácido lácticas termoresistentes en salchichas cocidas. Cienc. Tecnol. Aliment. 2006, 5, 135-141. [CrossRef]

27. Perez-Chabela, M.L.; Totosaus, A.; Guerrero, I. Evaluation of thermotolerant capacity of lactic acid bacteria isolated from commercial sausages and the effects of their addition on the quality of cooked sausages. Ciênc. Tecnol. Aliment. Campinas 2008, 28, 132-138. [CrossRef]

28. Rzepkowska, A.; Zielińska, D.; Ołdak, A.; Kołożyn-Krajewska, D. Safety assessment and antimicrobial properties of the lactic acid bacteria strains isolated from polish raw fermented meat products. Int. J. Food Prop. 2017, 20, 2736-2747. [CrossRef]

29. Hornsey, M. The colour of cooked cured pork. J. Agric. Sci. 1956, 9, 534. [CrossRef]

30. Siu, D.; Henshall, A. Ion chromatographic determination of nitrate and nitrite in meat products. J. Chromatogr. A 1998, 804, 156-160. [CrossRef]

31. Hunt, M.; King, A. Guidelines, instrumental meat color measurement. In AMSA Meat Color. Measurement Guidelines; American Meat Science Association: Champaign, IL, USA, 2012; Section VIII; pp. 45-52.

32. Kumar, D.; Tanwar, V.K. Effects of incorporation of ground mustard on quality attributes of chicken nuggets. J. Food Sci. Technol. 2011, 48, 759-762. [CrossRef] [PubMed]

33. Ha, M.Y.; Kim, S.W.; Lee, Y.W.; Kim, M.J.; Kim, S.J. Kinetics analysis of growth and lactic acid production in pH-controlled batch cultures of Lactobacillus casei KH-1 using yeast extract/corn steep liquor/glucose medium. J. Biosci. Bioeng. 2003, 96, 134-140. [CrossRef]

34. Vermeiren, L.; Devlieghere, F.; Debevere, J. Evaluation of meat born lactic acid bacteria as protective cultures for the biopreservation of cooked meat products. Int. J. Food Microbiol. 2004, 96, 149-164. [CrossRef]

35. Bolotin, A.; Mauger, S.; Malarme, K.; Ehrlich, S.D.; Sorokin, A. Low-redundancy sequencing of the entire Lactococcus lactis IL1403 genome. Lact. Acid Bact. Genet. Metab. Appl. 1999, 76, 27-76. 
36. Bolotin, A.; Wincker, P.; Mauger, S.; Jaillon, O.; Malarme, K.; Weissen-Bach, J.; Ehrlich, S.D.; Sorokin, A. The complete genome sequence of the lactic acid bacterium Lactococcus lactis ssp. lactis IL1403. Genome Res. 2001, 11, 1-23. [CrossRef]

37. Sanders, J.W.; Leenhouts, K.J.; Haandrikman, A.J.; Venema, G.; Kok, J. Stress response in Lactococcus lactis: Cloning, expression analysis, and mutation of the lactococcal superoxide dismutase gene. J. Bacteriol. 1995, 177, 5254-5260. [CrossRef] [PubMed]

38. Igarashi, T.; Kono, Y.; Tanaka, K. Molecular cloning of manganese catalase from Lactobacillus plantarum. J. Biol. Chem. 1996, 271, 29521-29524. [CrossRef]

39. Kulikowska-Karpińska, E.; Moniuszko-Jakoniuk, J. The antioxidative barrier in the organism. Pol. J. Environ. Stud. 2004, 13, 5-13.

40. Abriouel, H.; Herrmann, A.; Stärke, J.; Yousif, N.M.; Wijaya, A.; Tauscher, B.; Holzapfel, W.; Franz, C.M.A.P. Cloning and heterologous expression of hematin-dependent catalase produced by Lactobacillus plantarum CNRZ 1228. Appl. Environ. Microbiol. 2004, 70, 603-606. [CrossRef] [PubMed]

41. Lechardeur, D.; Cesselin, B.; Fernandez, A.; Lamberet, G.; Garrigues, C.; Pedersen, M.; Gaudu, P.; Gruss, A. Using heme as an energy boost for lactic acid bacteria. Curr. Opin. Biotechnol. 2011, 22, 143-149. [CrossRef] [PubMed]

42. Honikel, K.O. The use and control of nitrate and nitrite for the processing of meat products. Meat Sci. 2008, 78, 68-76. [CrossRef] [PubMed]

43. Benjamin, N.; Collins, J. Nitrite. In Food Preservatives, 2nd ed.; Russell, N.J., Gould, G.W., Eds.; Kluwer Academic/Plenum Publishers: New York, NY, USA, 2003; Volume 6, pp. 102-118.

44. Sindelar, J.J.; Milkowski, A.L. Sodium nitrite in processed meat and poultry meats: A review of curing and examining the risk/benefit of its use. Am. Meat Sci. Assoc. AMSA White Pap. Ser. 2011, 3, 1-14.

45. Terns, M.J.; Milkowski, A.L.; Claus, J.R.; Sindelar, J.J. Investigating the effect of incubation time and starter culture addition level on quality attributes of indirectly cured, emulsified cooked sausages. Meat Sci. 2011, 88, 454-461. [CrossRef]

46. Shin, D.M.; Hwang, K.E.; Lee, C.W.; Kim, T.K.; Park, Y.S.; Han, S.G. Effect of Swiss Chard (Beta vulgaris Var. cicla) as nitrite replacement on color stability and shelf-life of cooked pork patties during refrigerated storage. Korean J. Food Sci. 2017, 37, 418-428. [CrossRef] [PubMed]

47. Barbieri, G.; Bergamaschi, M.; Barbieri, G.; Franceschini, M. Kinetics of nitrite evaluated in a meat product. Meat Sci. 2013, 93, 282-286. [CrossRef]

48. Slima, S.B.; Ktari, N.; Trabelsi, I.; Triki, M.; Feki-Tounsi, M.; Moussa, H.; Makni, I.; Herrero, A.; Jiménez-Colmenero, F.; RuizCapillas Perez, C.; et al. Effect of partial replacement of nitrite with a novel probiotic Lactobacillus plantarum TN8 on color, physico-chemical, texture and microbiological properties of beef sausages. LWT Food Sci. Technol. 2017, 86, 219-226. [CrossRef]

49. Heaton, K.M.; Cornforth, D.P.; Moiseev, I.V.; Egbert, W.R.; Carpenter, C.E. Minimum sodium nitrite levels for 536 pinking of various cooked meats as related to use of direct or indirect-dried soy isolates in 537 poultry rolls. Meat Sci. 2000, 55, 321-329. [CrossRef]

50. Zeleňáková, L.; Kunová, S.; Lopašovský, L. Evaluation of microbiological quality of cooked meat products during their shelf life. Maso Int. Brno 2011, 1, 15-20.

51. Eskandari, M.H.; Hosseinpour, S.; Mesbahi, G.R.; Shekarforoush, S. New composite nitrite-free and low-nitrite meat-curing systems using natural colorants. Food Sci. Nutr. 2013, 1, 392-401. [CrossRef]

52. Patsias, A.; Chouliara, I.; Badeka, A.; Savvaidis, I.N.; Kontominas, M.G. Shelf-life of a chilled precooked chicken product stored in air and under modified atmospheres: Microbiological, chemical, sensory attributes. Food Microbiol. 2006, 23, 423-429. [CrossRef]

53. Comi, G.; Andyanto, D.; Manzano, M.; Iacumin, L. Lactococcus lactis and Lactobacillus sakei as bio-protective culture to eliminate Leuconostoc mesenteroides spoilage and improve the shelf life and sensorial characteristics of commercial cooked bacon. Food Microbiol. 2016, 58, 16-22. [CrossRef]

54. Feng, C.H.; Drummond, L.; Sun, D.W. Modelling the growth parameters of lactic acid bacteria and total viable count in vacuum-packaged Irish cooked sausages cooled by different methods. Int. J. Food Sci. Technol. 2014, 49, 2659-2667. [CrossRef]

55. Roszak, D.B.; Grimes, D.J.; Colwell, R.R. Viable but non-recoverable stage of Salmonella enteritidis in aquatic system. Can. J. Microbiol. 1984, 30, 334-338. [CrossRef]

56. Fakruddin, M.D.; Mannan, K.S.B.; Andrews, S. Viable but nonculturable bacteria: Food safety and public health perspective. ISRN Microbiol. 2013, 1-6. [CrossRef] [PubMed]

57. Li, L.; Mendis, N.; Trigui, H.; Oliver, J.D.; Faucher, S.P. The importance of the viable but non-culturable state in human bacterial pathogens. Front. Microbiol. 2014, 5, 258. [CrossRef]

58. Zielińska, D.; Ołdak, A.; Rzepkowska, A.; Zieliński, K. Enumeration and identification of probiotic bacteria in food matrices. In Advances in Biotechnology for Food Industry; Holban, A.M., Grumezescu, A.M., Eds.; Academic Press: New York, NY, USA, 2018; Chapter 6; pp. 167-196.

59. Majou, D.; Christieans, S. Mechanisms of the bactericidal effects of nitrate and nitrite in cured meats. Meat Sci. 2018, 145, 273-284. [CrossRef] [PubMed]

60. Sebranek, G.J.; Bacus, J.N. Cured meat products without direct addition of nitrate or nitrite: What are the issues? Meat Sci. 2007, 77, 136-147. [CrossRef] [PubMed]

61. Sebranek, G.J. Basic Curing Ingredients. In Ingredients in Meat Products: Properties, Functionality, and Applications; Tarte, R., Ed.; Springer Science Business Media: New York, NY, USA, 2009; pp. 1-23. 
62. Lövenklev, M.; Artin, I.; Hagberg, O.; Borch, E.; Holst, E.; Radström, P. Quantitative interaction effects of carbon dioxide, sodium chloride, and sodium nitrite on neurotoxin gene expression in nonproteolytic Clostridium botulinum Type, B. Appl. Environ. Microbiol. 2004, 70, 2928-2934. [CrossRef] [PubMed]

63. Lövenklev, M.; Artin, I.; Hagberg, O.; Borch, E.; Holst, E.; Radström, P. Relative neurotoxin gene expression in Clostridium botulinum type B, determined using quantitative reverse transcription-PCR. Appl. Environ. Microbiol. 2004, 70, $2919-2927$. [CrossRef] 